\section{Organizations Endorsing The Statement On Faculty Status}

The following organizations have endorsed the statement on faculty status:

Association of College and

Research Libraries

Colorado Library Association

American Association of

University Professors

Wisconsin Association of Academic Librarians

Association of Academic and Research Libraries, Washington Library Association

Southeastern Library Association

New Mexico Library Association

District of Columbia Library Association

Mississippi Library Association

West Virginia Library Association

Tennessee Library Association

Virginia Library Association

Oregon Library Association
June 1972

December 1972

April 1972

April 1972

May 1973

July 1973

July 1973

July 1973

July 1973

July 1973

July 1973

August 1973

September 1973
Southwestern Library

Association

Ohio Library Association

Florida Library Association

Missouri Library Association

California Library Association

Special Libraries Association

Association of Research

Libraries"

Wisconsin Library Association

College and University

Section, Georgia Library

Association

Georgia Library Association

Academic Division, Minnesota Library Association

Theatre Library Association

Rhode Island Library

Association

September 1973

September 1973

September 1973

September 1973

September 1973

October 1973

October 1973

October 1973

October 1973

October 1973

October 1973

October 1973

November 1973

A draft version of the statement was endorsed in principle by the North Carolina State Board of Higher Education, Advisory Committee of Librarians, in May 1972.

"VOTED "that the Board endorse in principle faculty status for professional librarians, and commend to the attention of all college and university administrations the "Joint Statement on Faculty Status of College and University Librarians." "

\title{
Librarians Win Williams \& Wilkins Reversal
}

Robert Wedgeworth, executive director of $A L A$, recently issued the following statement on the Williams \& Wilkins decision.

On November 27, 1973, the U.S. Court of Claims issued a historic decision with respect to Williams \& Wilkins vs, the United States. Plaintiff, the Williams \& Wilkins Company, a medical publisher, had charged that the Department of Health, Education and Welfare (HEW) through the National Institute of Health (NIH) and the National Library of Medicine (NLM) had infringed plaintiff's copyrights in certain of its medical journals by making unauthorized photocopies of articles from those journals. The court decided in favor of the government in this case. The key factor in the decision in the court's opinion was that the plaintiff failed to sustain the assumption that the defendant's photocopying activities were, in fact, injurious to the financial health of the journals concerned. While we may hail this as an important victory, we must keep in mind that the court in- dicated in its decision that the problem of photocopying materials under copyright would be best resolved through legislation. This means that with respect to a revision of the copyright law, there is a great deal of work ahead in order to assure that such a law protects the public interest with respect to access to information consistent with the decision of the U.S. Court of Claims.

\section{ConRection}

A sharp-eyed reader informs us that our item about Inforasia on page 275 in the November (No. 10) issue has a typographic error which may lead to problems with the Japanese post office. The address of the Japan English Service is correct up to the prefecture. The Chiga-ken is in reality Chiba-ken. Sorry. 